\title{
Development of Kudoa thyrsites (Myxozoa: Myxosporea) in netpen-reared Atlantic salmon determined by light microscopy and a polymerase chain reaction test
}

\author{
J. D. W. Moran ${ }^{1,2}$, L. Margolis ${ }^{2}$, J. M. Webster ${ }^{1}$, M. L. Kent ${ }^{2, *}$ \\ ${ }^{1}$ Department of Biological Sciences, Simon Fraser University, 8888 University Drive, Burnaby, British Columbia V5A 1S6, Canada \\ ${ }^{2}$ Pacific Biological Station, Department of Fisheries and Oceans, 3190 Hammond Bay Road, Nanaimo, British Columbia \\ V9R 5K6, Canada
}

\begin{abstract}
The intramuscular phase of development of Kudoa thyrsites, the myxosporean associated with post-mortem myoliquefaction, or 'soft flesh syndrome', is described using histological preparations of the musculature of seawater netpen-reared Atlantic salmon Salmo salar. Hatchery-reared Atlantic salmon were naturally exposed to the infective stage while held in the experimental seawater netpens of the Pacific Biological Station in Nanaimo, British Columbia, Canada. In fish exposed during the summer of $1995, K$. thyrsites infections were first detected in the somatic musculature at 13 wk postexposure (p.e.) using only light microscopy. In the 1997 exposure, infections were first detected at 6 wk p.e. using a PCR test and at 9 wk p.e. using light microscopy. The earliest stage detected by histology was a small plasmodium containing 4 nuclei. No host response was observed that was directly related to the presence of intact plasmodia within muscle fibers. However, a response was associated with ruptured plasmodia, which was characterized by chronic, multifocal inflammation between the muscle fibers
\end{abstract}

KEY WORDS: Atlantic salmon - Kudoa thyrsites - Multivalvulida - Marine myxosporean - Salmo salar Soft flesh syndrome

\section{INTRODUCTION}

Several species of myxosporeans (phylum Myxozoa) have their sporogonic phase in the musculature of freshwater and marine fishes. These histozoic species are represented in genera such as Myxobolus, Unicapsula, Henneguya, and Kudoa. Some of the most documented species are members of the multivalvulid genus Kudoa, which is presently comprised of 44 species of parasites (Moran et al. 1999a). Many species within this genus are associated with post-mortem myoliquefaction, which is commonly referred to as 'soft flesh syndrome' (see reviews by Egusa 1986, Moran et al. 1999a). Kudoa thyrsites has been implicated as a cause of soft flesh syndrome in farmed Atlantic Salmo salar and coho Oncorhynchus kisutch

-Addressee for correspondence. E-mail: kentm@dfo-mpo.gc.ca salmon reared in British Columbia (BC) seawater netpens (Whitaker \& Kent 1991, Kent et al. 1994, Kent \& Poppe 1998). However, concern about $K$. thyrsites infections is not limited to $\mathrm{BC}$ aquaculturalists as this parasite has both a worldwide distribution and wide host range (Moran \& Kent 1999, Moran et al. 1999a).

The early development of several myxosporean genera (e.g. Myxobolus, Sphaerospora, Sphaeromyxa, Myxidium, Hoferellus, Ceratomyxa, and Kudoa), as well as the enigmatic proliferative kidney disease organism (PKX) has been described (see reviews by Lom \& Dyková 1992, Moser \& Kent 1994). Myxosporean development may include a proliferative phase in a site other than that of sporulation, and is referred to as an extrasporogonic phase (Lom \& Dyková 1992). This phase has been reported among members of the Sphaerospora (cf. Csaba 1976) and Myxobolus (cf. El-Matbouli et al. 1995) genera. As 
well, the PKX trophozoite represents the extrasporogonic stage of an undescribed species (Kent \& Hedrick 1986). Although extrasporogonic development has not been reported for any member of the genus Kudod, it was recently reported that $K$. thyrsites can be experimentally transmitted by blood injections, which suggests that extrasporogonic development may occur in this species (Moran et al. 1999b).

Sporogenesis in myxozoans may occur by either development in pansporoblasts or direct spore morphogenesis within plasmodia (Lom \& Dyková 1992). Within the genus Kudoa, sporogenesis has been investigated using electron microscopy in both $K$. lunata (cf. Lom \& Dyková 1988) and K. paniformis (cf. Stehr 1986). In both $K$. lunata and $K$. paniformis, sporogenesis occurs without the formation of pansporoblasts (Lom \& Dyková 1992).

In this study, we describe the results of experiments using a combination of histological and polymerase chain reaction (PCR) screening that provide further details on the development of Kudod thyrsites within the Atlantic salmon host and observations of the host response to these infections.

\section{MATERIALS AND METHODS}

1995-97 experiment. All experiments were conducted at the Pacific Biological Station (PBS), in Nanaimo, BC. Atlantic salmon $(N=450)$ reared at a freshwater hatchery were naturally exposed to Kudoa thyrsites at the PBS experimental seawater netpens situated near the research station. They were held at the site from 25 May to 8 June 1995 to permit natural exposure to $K$. thyrsites. After this 2 wk natural exposure period, the fish were returned to three, $400 \mathrm{l}$ tanks supplied with flow-through, sand-filtered sea water for the remainder of the experiment. Samples of 25 fish were collected at $4,8,13,17$, and 26 wk post-exposure (p.e.). The remaining samples collected at $35,52,70$, and 87 wk p.e. varied in size at 10,15, 15, and 17 fish, respectively. Mean seawater temperature was $10^{\circ} \mathrm{C}$ (range $=8$ to $15^{\circ} \mathrm{C}$ ) for the experiment's duration (i.e. 25 May 1995 to 23 January 1997). All fish were maintained on an artificial, commercial diet.

Detection of Kudoa infections was by examination of wet mount preparations, as described in Moran et al. (1999b), by histological preparation, or by a combination thereof. Samples of the gill, muscle, stomach, pyloric caeca, posterior intestine, kidney, gonad, and spleen were collected and fixed in Davidson's solution for histological processing. Sections were stained using hematoxylin and eosin. The presence of blood stages was also assessed using blood smears. Blood was collected from the severed caudal vessel using heparinized capillary tubes. The thin blood smears were stained using either Leukostat (Fisher) or DiffQuik (Baxter) stains.

1997 experiment. Hatchery-reared, Atlantic salmon $(N=450)$ were transferred to the PBS experimental seawater netpens for the $26 \mathrm{wk}$ exposure period of 9 June to 9 December 1997. Mean seawater temperature was $14^{\circ} \mathrm{C}$ (range $=8$ to $22^{\circ} \mathrm{C}$ ) for the duration of the natural exposure period. Samples of 25 salmon were collected at 3,6 , and $9 \mathrm{wk}$ p.e. The remaining sample sizes collected at 12,15 , and 26 wk p.e. were 24,22 , and 9 fish, respectively. Organs, as listed above, were collected and prepared for histological examination in the manner previously described.

Blood, gill, muscle, skin, and intestine samples were collected from the first 10 fish at each sample date (with the exception of the 26 wk p.e. sample of 9 fish) for the 1997 study only, and were fixed in 100\% ethanol. DNA preparations made from each sample were analysed with the Kudoa thyrsites-specific PCR test described by Hervio et al. (1997). Samples of 25 to $50 \mathrm{mg}$ of tissue or 50 to $100 \mu \mathrm{l}$ of whole blood were lysed in $10 \mathrm{mM}$ Tris, $1 \mathrm{mM}$ EDTA, pH 8.0, $1 \%$ SDS containing proteinase $\mathrm{K}\left(200 \mu \mathrm{g} \mathrm{ml}^{-1}\right)$ for at least $4 \mathrm{~h}$ at $37^{\circ} \mathrm{C}$ with agitation. Samples were extracted twice using the standard phenol: chloroform: isoamyl alcohol (50:50:1) mixture, precipitated with chilled isopropyl alcohol and sodium acetate and centrifuged at $10000 \mathrm{rpm}(8160 \times g)$. The pelleted DNA was air-dried before being resuspended in $100 \mu \mathrm{l}$ of Tris EDTA (TE) buffer ( $10 \mathrm{mM}$ Tris, 1 mM EDTA, pH 8.0) and stored at $4^{\circ} \mathrm{C}$. The amount of DNA collected from each sample was quantified using a spectrophotometer. Each solution was diluted in TE to prepare the PCR template working solution (300 to $500 \mathrm{ng}$ of DNA). PCR reactions $(50 \mu \mathrm{l})$ included the following constituents: $10 \times$ PCR buffer $(5 \mu \mathrm{l}) ; 2 \mathrm{mM}$ dNTPs $(5 \mu \mathrm{l}) ; 50 \mathrm{mM} \mathrm{MgCl} \mathrm{Mg}_{2}$ $(1.5 \mu \mathrm{l}) ; 20 \mathrm{pMol}^{-1} \mathrm{l}^{-1} \mathrm{Kt} 18 \mathrm{~S} 1 \mathrm{r}(1.25 \mu \mathrm{l})$ (reverse primer); $20 \mathrm{pMol} \mathrm{ll}^{-1} \mathrm{Kt} 18 \mathrm{~S} 6 \mathrm{f}(1.25 \mu \mathrm{l})$ (forward primer); 5 units $\mu \mathrm{l}^{-1}$ Taq $(0.25 \mu \mathrm{l})$; double-distilled $\mathrm{H}_{2} \mathrm{O}(32.75 \mu \mathrm{l})$; and DNA template $(3 \mu \mathrm{l})$. The PCR cycles included a $3 \mathrm{~min}$ denaturation at $95^{\circ} \mathrm{C}$, followed by 30 to 35 cycles $\left(94^{\circ} \mathrm{C}\right.$ for $1 \mathrm{~min}, 60^{\circ} \mathrm{C}$ for $1 \mathrm{~min}, 72^{\circ} \mathrm{C}$ for $1.5 \mathrm{~min}$ ). After all cycles were completed, the process concluded with a $10 \mathrm{~min}$ extension at $72^{\circ} \mathrm{C}$. Agarose gels $(1.25 \%)$ were run at $100 \mathrm{~V}$ for $1 \mathrm{~h}$. Positive results were indicated by a product equivalent to 909 base pairs in size.

\section{RESULTS}

\section{Light microscope observations}

Plasmodia were first detected at $13 \mathrm{wk}$ p.e. in 1995 and at $9 \mathrm{wk}$ p.e. in 1997. The earliest stage of develop- 


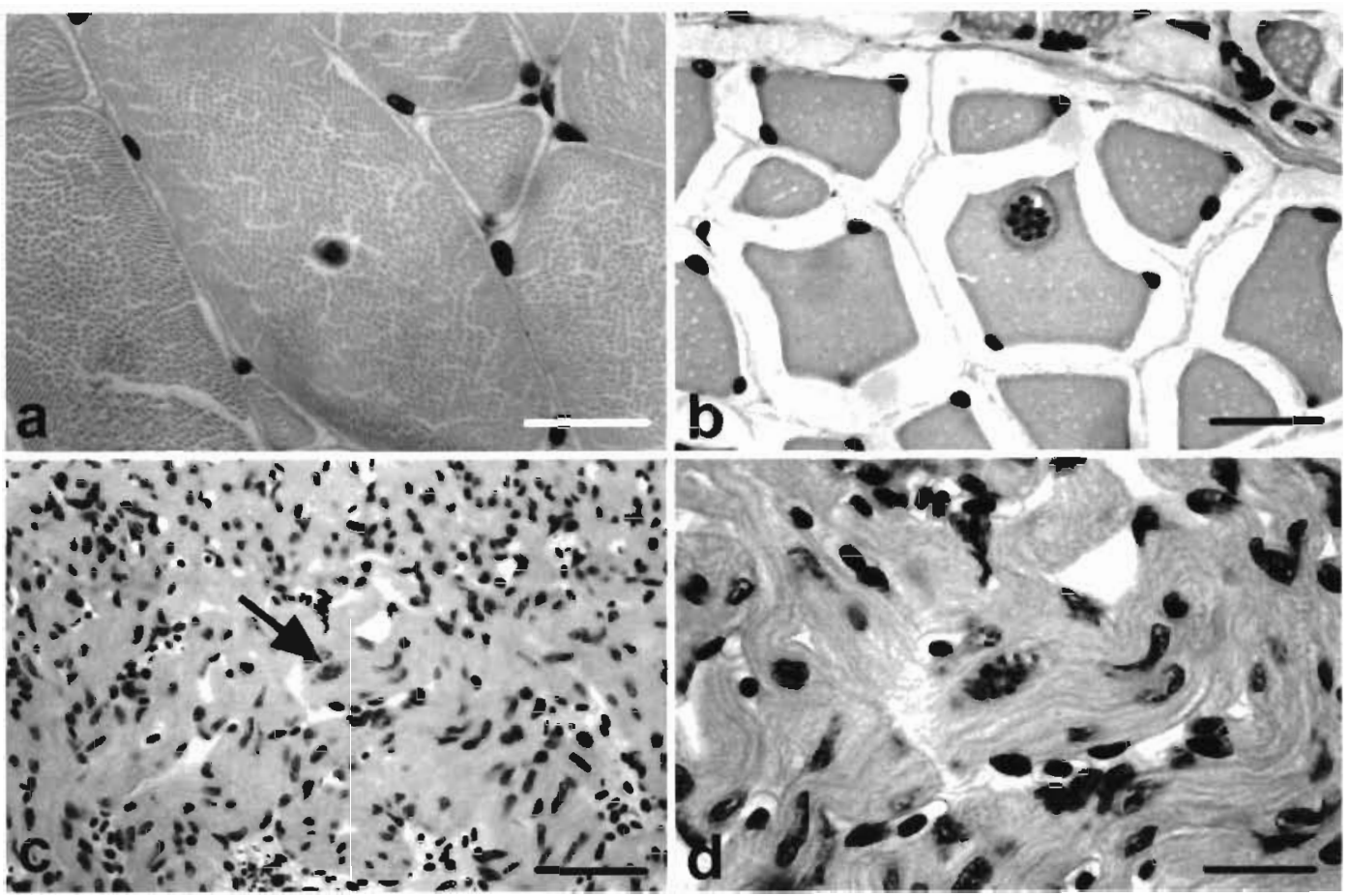

Fig. 1. Salmo salar. Developing plasmodia of Kudoa thyrsites within the musculature. (a) Presporogonic plasmodium within the somatic musculature. Scale bar $=30 \mu \mathrm{m}$. (b) Presporogonic plasmodium containing very early developmental stages of $K$. thyrsites. Scale bar $=20 \mu \mathrm{m}$. (c) Early plasmodial stage (arrow) developing within the cardiac musculature. Scale bar $=70 \mu \mathrm{m}$.

(d) Increased magnification of (c). Scale bar $=20 \mu \mathrm{m}$

ment observed was in the somatic musculature, detected at 9 wk p.e. (Fig. 1a). This plasmodium was approximately $7 \mu \mathrm{m}$ in diameter and contained about 4 internal cells (or nuclei). A slightly larger plasmodial stage $(11 \mu \mathrm{m})$ containing several cells also was observed in the somatic musculature (Fig. 1b). Developing plasmodia were detected within the cardiac muscle of Atlantic salmon at 17 wk p.e. (Fig. 1c,d). The plasmodia in the muscle fibers continued to increase in size as the sporogenesis progressed (Fig. 2). Polysporic plasmodia contained fully formed myxospores in the center and developing myxospores were situated around the periphery of the plasmodia (Fig. 2d).

No inflammatory response was associated with somatic or cardiac muscle fibers that contained developing plasmodia or intact plasmodia with fully formed myxospores (Figs. 1 \& 2). The host response was evident only after muscle fibers and the plasmodial wall were lysed, releasing the myxospores and other cytoplasmic constituents into the endomysium. This host response to infection was characterized by multifocal, chronic inflammation between the muscle fibers. As well, macrophages engulfed myxospores that were released from ruptured plasmodia (Fig. 3). Inflammation was first detected at $8 \mathrm{wk}$ p.e. in 1995, and at $6 \mathrm{wk}$ p.e. in 1997 (Figs. 4 \& 5).

\section{5-97 experiment}

The results of this experiment are shown in Fig. 4. A single presporogonic plasmodium was first detected at 13 wk p.e. in the somatic musculature. Aggregates of trophozoites and plasmodia containing developing myxospores were observed in the cardiac muscle at 17 wk p.e. (Fig. 1c,d). Presporogonic plasmodia reached a maximum prevalence of $40 \%$ at $26 \mathrm{wk}$ p.e., and were not observed after this sample. Infections containing fully formed myxospores reached a maximum prevalence of $64 \%$ at $26 \mathrm{wk}$ p.e. and fish recovered from these infections within $1 \mathrm{yr}$. The pattern of the inflammatory response showed complete resolution (i.e. was undetectable) by the end of the experiment (Fig. 4).

No stages suggestive of myxosporeans were observed in the blood smears.

\section{7 experiment}

Kudoa thyrsites infections were not detected histologically in the somatic musculature until 9 wk p.e. (Fig. 5). At this time, a single presporogonic plasmodium was observed (Fig. 1a). The prevalence of inflammation coincided with the infections (Fig. 5). Com- 


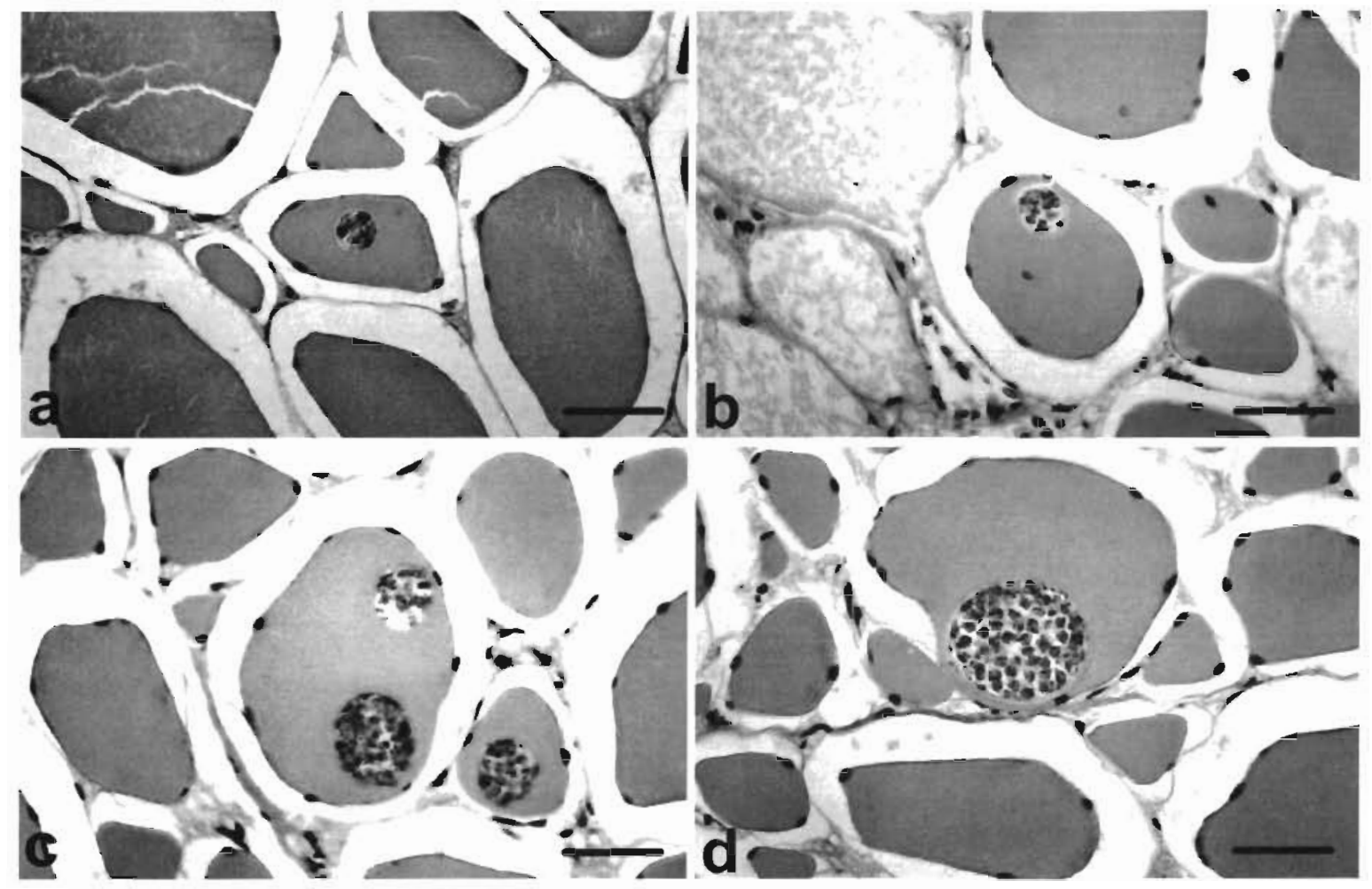

Fig. 2. Salmo salar. Sporogonic plasmodia of Kudoa thyrsites within the somatic musculature. (a, b) Early sporogonic plasmodia within the somatic musculature with developing myxospores. Scale bar $=40 \mu \mathrm{m}$. (c) Apparent double infection of a muscle fiber by plasmodia. Scale bar $=70 \mu \mathrm{m}$. (d) Plasmodium with fully formed myxospores of $K$. thyrsites. Scale bar $=60 \mu \mathrm{m}$

pared with the previous study, both the prevalence and intensity of the infections were less.

No Kudoa thyrsites infections were detected in the first 3 wk p.e. using the PCR test. The prevalence of infection reached a maximum of $80 \%(8 / 10)$ at 6 wk p.e., and all of the tissues sampled (i.e. blood, gill, muscle, skin, and intestine) were positive for infection (Fig. 5). Infections were detected in the muscle and skin at $9 \mathrm{wk}$ p.e., and in only the muscle at $12 \mathrm{wk}$ p.e. At 15 wk p.e., the infections were detected in the somatic muscle and skin of $1 \mathrm{fish}$, and in only the intestine of all other fish determined to be positive by PCR. At 26 wk p.e., the lone positive signal was from a gill sample (Fig. 6).

\section{DISCUSSION}

The genus Kudoa is comprised of species that are described primarily as parasites of the skeletal musculature (see reviews by Egusa 1986, Lom \& Dyková 1992, Moran et al. 1999a). Several of the species (e.g. $K$. Iunata, K. miniauriculata, K. paniformis, K. thyrsites) are intracellular parasites as their site of infection is within the muscle fiber (Gilchrist 1924, Kabata \& Whitaker 1981, Lom et al. 1983, Whitaker et al. 1996).
In intracellular stages of $K$. thyrsites, the only boundary between the early developmental stages and the muscle fiber was the parasite's cell membrane (Figs. 1 $\& 2$ ). Consequently, $K$. thyrsites can be regarded as an intracellular parasite of Atlantic salmon.

Plasmodia of histozoic myxosporeans produce spores either following division in the pansporoblasts or by direct spore morphogenesis (Lom \& Dyková 1992). Pansporoblasts, which originate by the union of 2 generative cells, usually develop to produce 2 spores (Lom \& Dyková 1992). Pansporoblast formation is seen in myxosporean species that produce large plasmodial trophozoites, such as Sphaeromyxa, Myxobolus, and Myxidium. Based upon the results of electron microscopic studies of Kudoa lunata (cf. Lom \& Dyková 1988) and $K$. paniformis (cf. Stehr 1986), it has been suggested that Kudoa spp. may not produce pansporoblasts but, instead, undergo direct spore morphogenesis. In this process, sporogonic cells produce sporoblasts that give rise to valvogenic, capsulogenic, and sporoplasmic cells. Each cell then assumes its predetermined role in the formation of spores (Lom \& Dyková 1992). Direct spore morphogenesis is seen in pseudoplasmodia of Sphaerospora and Ceratomyxa, and in some histozoic multivalvulid species (Lom \& Dyková 1988). In $K$, thyrsites infections of Atlantic 


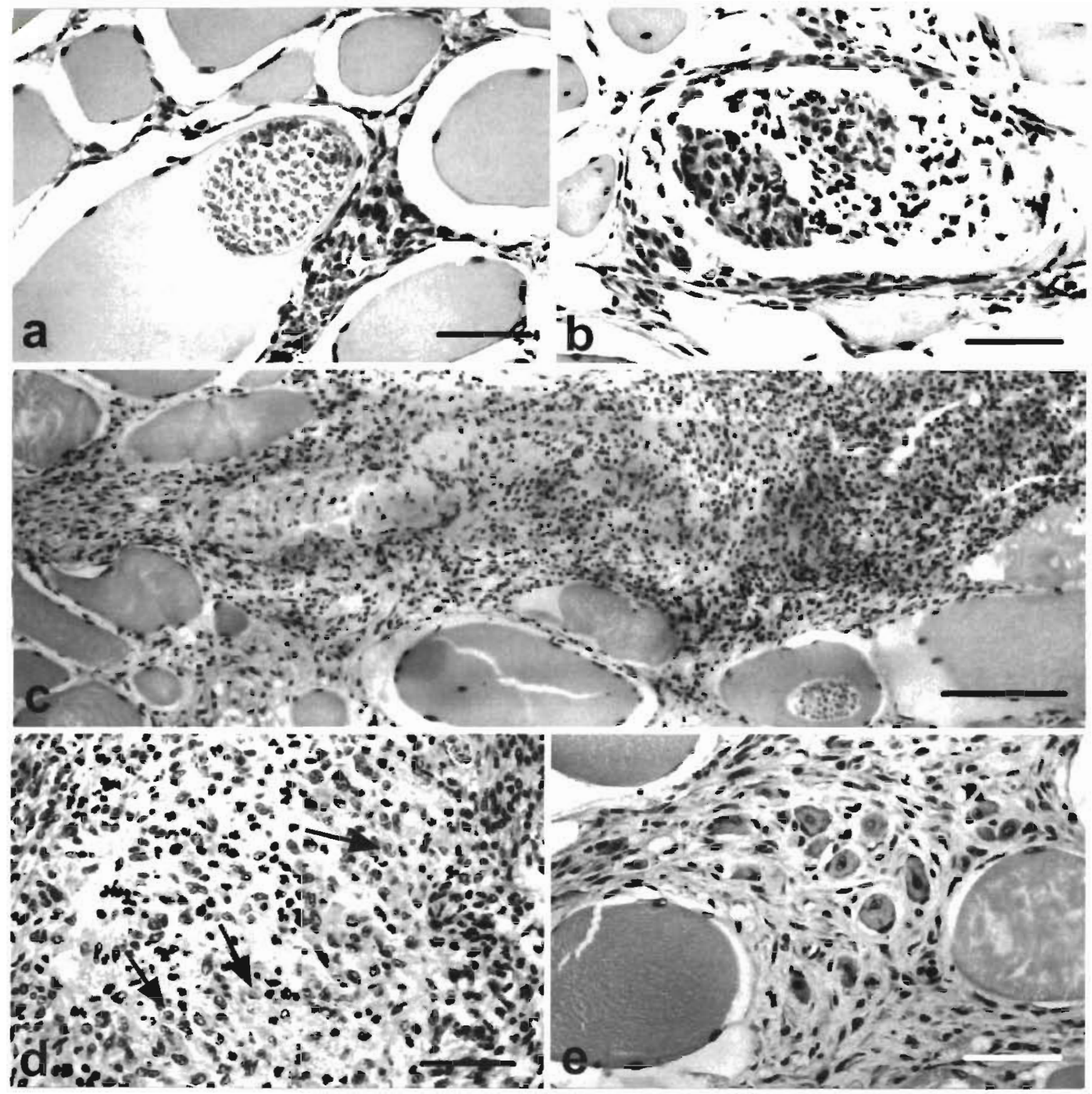

Fig. 3. Salmo salar. Inflammation associated with Kudoa thyrsites infections. (a) Intact polysporic plasmodium within a muscle fiber. The inflammation within the endomysium is not associated with this plasmodium. Scale bar $=80 \mu \mathrm{m}$. (b) Granuloma with myxospores of $K$. thyrsites between the muscle fibers. Scale bar $=80 \mu \mathrm{m}$. (c) Chronic, extensive inflammation between the muscle fibers as seen in cross-section. Scale bar $=200 \mu \mathrm{m}$. (d) Myxospores of $K$. thyrsites (arrows) within phagocytes. Scale bar $=20 \mu \mathrm{m}$. (e) Regenerating muscle fibers during resolution of infection. Scale bar $=80 \mu \mathrm{m}$

salmon, once the parasite has become established within the muscle fiber, the polysporic plasmodium apparently does not undergo division, but instead increases greatly in size.

Using histology and blood smears, we were unable to observe developmental stages of Kudoa thyrsites in sites other than the somatic and cardiac musculture. The development of the trophozoite stage of myxosporeans within the fish host may include a proliferative phase in tissues or organs different from the final site (i.e. extrasporogonic phase). Extrasporogonic stages of Sphaerospora spp. have been observed in the blood, swimbladder, and rete mirabile of the eye, and within the cerebral axons and epidermis for various Myxobolus spp. (cf. Lom \& Dyková 1992). This proliferative phase may also induce 'xenoma' formation, as has been observed with Myxidium lieberkuehni infections in pike Esox lucius (cf. Lom et al. 1989). Such a proliferative cycle has yet to be described for Kudoa species. However, it has been determined that a stage of $K$. thyrsites occurs in the blood and may be transmitted to naive salmon by intraperitoneal injection, albeit with 


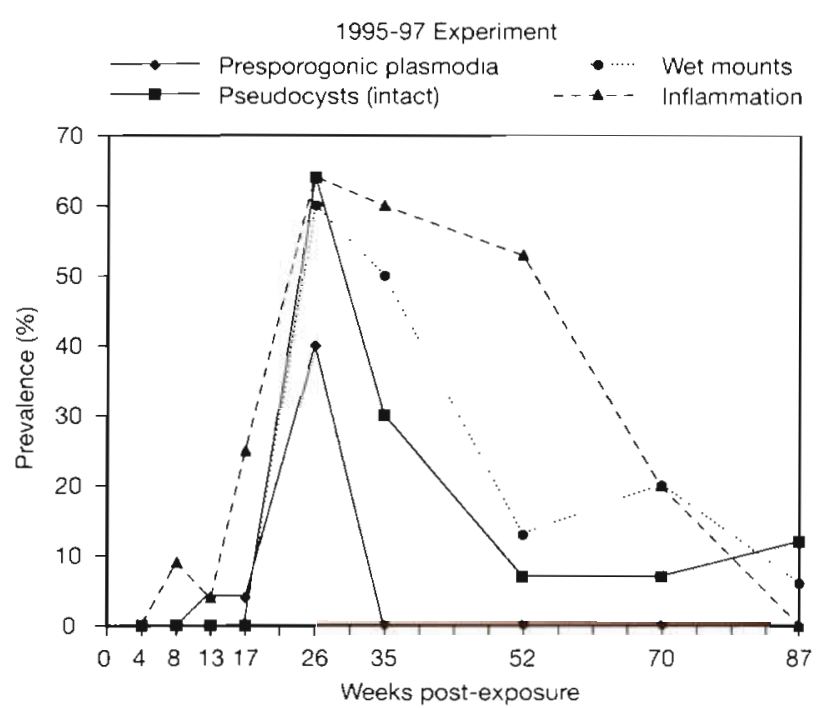

Fig. 4. Salmo salar. Prevalence of Kudoa thyrsites stages and associated inflammation in the musculature using a combination of histology and wet mount preparations in fish first exposed 25 May 1995

low success (Moran et al. 1999b). Our attempts to observe this stage in blood smears were unsuccessful, which may signify that it is transient and undergoes little, if any, proliferation within the blood.

There is brief mention of the presence of early stages of either Kudoa thyrsites or K. paniformis in the muscle fibers of Pacific hake Merluccius productus (Morado \& Sparks 1986). However, the 'putative infective stage' observed by Morado \& Sparks (1986) appears to be a myxospore engulfed by a macrophage. Gilchrist (1924)

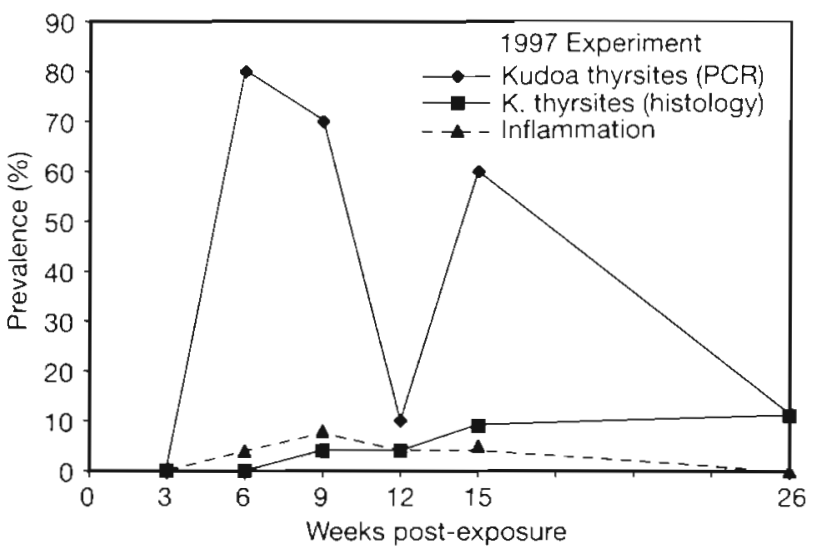

Fig. 5. Salmo salar. Prevalence of Kudoa thyrsites stages and associated inflammation in the musculature of Atlantic salmon using histological examination of fish first exposed 9 June 1997. The prevalence of infection was also determined by screening various tissues (i.e. blood, gill, muscle, skin, and intestine) using the $K$. thyrsites-specific PCR test developed by Hervio et al. (1997)

provided some details on the early developmental stages of $K$. thyrsites, but we did not observe the long chains of cells that he described. Stehr (1986) provided ultrastructural details of the generative cells in plasmodia containing fully formed myxospores of $K$. paniformis

In the 1995-97 experiment, presporogonic plasmodia were first detected in the somatic musculature of $4 \%$ of the fish at 13 wk p.e., reached a maximum prevalence of $40 \%$ at 26 wk p.e., and were not observed in any of the later samples (Fig. 4). Plasmodia with fully formed myxospores were not detected until 26 wk p.e., at

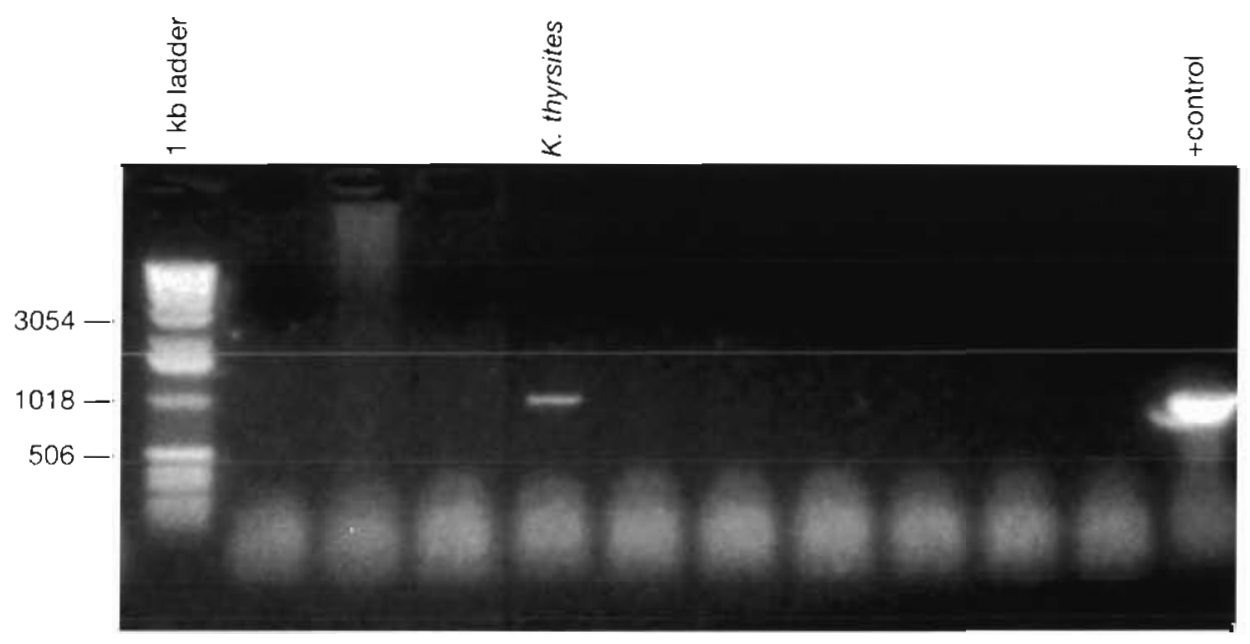

Fig. 6. Salmo salar. PCR of DNA from Atlantic salmon tissues at 26 wk p.e. screened using the Kudoa thyrsites-specific PCR test. Atlantic salmon were naturally exposed at the experimental seawater netpens located at the Pacific Biological Station, in Nanaimo, British Columbia, beginning 9 June 1997. The parasite DNA was amplified using the primers Kt18S6f and Kt18S1r (1.25\% agarose gel, ethidium-bromided stained). Positive control used $K$. thyrsites from snoek Thrysites atun collected off South Africa (lane 12). A positive signal from gill tissue, equivalent to 909 base pairs (bp), indicating a $K$. thyrsites infection is seen in lane 5. Negative tissue samples are demonstrated in lanes 2-4 and 6-11. Molecular weight markers (bp) are shown in the left lane 
which time the prevalence was $64 \%$, using histology The prevalence of these plasmodia decreased in later samples, but increased again in the $87 \mathrm{wk}$ sample. This slight increase in prevalence over the previous 2 samples may be the result of a second exposure to Kudoa thyrsites during the summer of 1996. The higher prevalence of infection observed in later samples using wet mount preparations, compared with that using histology, is probably because more tissue was used in the former. As well, the wet mount preparation enables visual detection of myxospores within both plasmodia and in inflammatory lesions.

In the 1995-97 experiment, inflammation in the somatic musculature was first observed in salmon at 8 wk p.e., which was prior to detection of the parasite in the muscle by microscopy (Fig. 4). This may have been associated with a different pathogen, as these fish were exposed in seawater netpens. Conversely, it is possible that this was a mild inflammatory response to cryptic, extrasporogonic stages migrating to the muscle fibers. In the 1997 experiment (Fig. 5), early stages of the parasite were present in many fish (as demonstrated by the PCR test) that were undetectable using light microscopy.

The general pattern of inflammation coincided with the Kudoa thyrsites infections in the Atlantic salmon until the host response was completely resolved by 87 wk p.e. (Fig. 4). The host response was one of chronic inflammation surrounding the parasites that were released from disrupted plasmodia. No inflammatory response was observed in the muscle fibers of Atlantic salmon that contained developing plasmodia and plasmodia containing fully formed myxospores (Figs. $1 \& 2$ ). Even when the plasmodia were in close proximity to the sarcolemma, no host response was evident (Fig. 2d). Presumably, only after the muscle fiber is ruptured, releasing the myxospores and other cytoplasmic constituents of the plasmodia into the endomysium, does the host response occur (Fig. 3). In our study, myxospores that were released from ruptured plasmodia were actively engulfed by macrophages. Lom \& Dyková (1995) described host responses to myxosporean infections as cell and tissue reactions that do not usually target the early developmental stages, and significant inflammation is usually not observed until fully formed myxospores are observed. Lom \& Dyková (1992) suggested that this host response may be the result of an increased antigenicity associated with the later developmental stages. Once inflammation occurs in $K$. thyrsites infections, the myxospores are ingested by macrophages and subsequently destroyed. The inflammatory response is apparently followed by complete resolution of the infection and associated lesions (Fig. 4). Both Morado \& Sparks (1986) and Stehr \& Whitaker (1986) investi- gated the host-parasite relationship between Pacific hake and Kudoa infections. The infections were described as deep within the muscle fibers with plasmodial growth along the length of the fiber. There was no hypertrophy in the infected fiber, and adjacent, uninfected muscle fibers were not affected. Morado \& Sparks (1986) concluded that the host was not able to recognize the parasites developing within the muscle fibers until the fiber was either replaced or necrotic. They also observed asynchronous myxospore development and plasmodial branching in $K$. paniformis infections of Pacific hake. This branching of $K$. paniformis plasmodia may give the appearance of multiple infections in some muscle fibers and may explain the appearance, in our experiments, of multiple $K$. thyrsites infections within a muscle fiber (Fig. 2c).

Resistance to reinfection has been observed in other myxosporean infections such as PKX and Ceratomyxa shasta (cf. Ferguson 1981, Bartholomew 1998). Ferguson (1981) and Clifton-Hadley et al. (1986) investigated this resistance in PKX infections in rainbow trout Oncorhynchus mykiss and determined that those fish that survived the initial PKX infections did not develop clinical disease after re-exposure to the parasite's infective stage. Similarly, Foott \& Hedrick (1987) discussed the resistance of re-exposed rainbow trout to PKX and theorized that this resistance was the result of an acquired immunity to the parasite from the initial exposure, as opposed to the increased age of the fish prior to exposure being a protective factor. With regards to Kudoa thyrsites infections in Atlantic salmon, it is unknown whether the fish are resistant to subsequent infections after the initial infection has been resolved. Moran \& Kent (1999) investigated these infections in post-smolt Atlantic salmon and suggested that the extremely high prevalence of infection is likely the result of the stress associated with smoltification, and the subsequent immunocompromised state of the fish. St-Hilaire et al. (1998) investigated the prevalence of these infections in sexually mature and immature netpen-reared Atlantic salmon and found that sexually mature fish were 13 times more likely to be infected. They suggested that this difference may be the result of immunosuppression associated with sexual maturation, therefore predisposing mature fish to these infections. With the present data, it is impossible to determine whether fish that are infected as smolts are immune to re-infection (i.e. it is unknown whether grilse and reconditioned grilse with $K$. thyrsites infections are fish that have recovered from previous infections during their first year in sea water). This aspect of resistance must be investigated in greater detail with $K$. thyrsites to determine whether vaccine development could be a viable alternative to chemotherapeutic treatment. 
Histology and wet mount preparations are the 2 most common methods used for detecting Kudoa thyrsites infections, and they appeared to be equally effective when myxospores are present (Fig. 4). However, wet mount preparations are difficult for use in detecting presporogonic plasmodia. This method only detects fully formed myxospores, as the early developmental stages are destroyed during the preparation. Hervio et al. (1997) demonstrated the increased sensitivity of their PCR test for detecting $K$. thyrsites infections in host tissues when compared with the standard wet mount techniques. The 1997 experiment (Fig. 5) followed a pattern similar to the 1995-97 experiment. Unfortunately, the apparent level of natural exposure was too low for conclusive results, as both the prevalence and the intensities of infections remained low throughout the experiment. However, the data are important in demonstrating the increased sensitivity of the PCR test in detecting $K$. thrysites infections when compared with standard screening techniques (i.e. wet mount preparations and histology). An anomalous drop in the prevalence, as detected by the PCR test, occurred at 12 wk p.e. This was unlikely the result of testing problems (e.g. contaminated primers) as both the negative and positive controls worked properly, and may actually reflect the problems inherent in small sample sizes. The PCR results that we obtained indicated that there were parasite stages in all of the tissues that were screened (i.e. blood, gill, muscle, skin, and intestine). It is likely that the positive PCR signals resulted from detecting the circulating extrasporogonic stages in the blood in these organs. With respect to screening for $K$. thyrsites infections, the PCR assay is more effective in that it not only detects all stages of the parasite (when compared to wet mount preparations), but does so by utilizing a greater amount of tissue (25 to $50 \mu \mathrm{g}$ versus a $5 \mu \mathrm{m}$ section). Therefore, PCR increases the possibility of detecting sparsely occurring stages in light to moderately infected fish as compared with histological screening.

The infective stage of Myxobolus cerebralis has been identified and can be propagated in the laboratory. Using this model, El-Matbouli et al. (1995) provided the most detailed description to date of the early development of myxosporeans within a fish host. The presumptive alternate host and infective stage of Kudoa thyrsites has not been identified; thus at present, we can consistently infect fish with $K$. thyrsites only by natural exposure. Presumably when this infective stage is found, it will be possible to experimentally induce massive infections, which would allow us to more precisely identify and describe the extrasporogonic stages and presporogonic plasmodia of $K$. thyrsites.
Acknowledgements. The authors wish to thank R. Kennedy and L. Lewington for fish maintenance during the natural exposures at the PBS experimental seawater netpens. We would also like to acknowledge the assistance in this project of the staff of the fish health section and histology unit of the PBS. Laboratory space and assistance with the PCR screening were provided by Dr R. H. Devlin and J. Khattra of the West Vancouver Laboratory. Special acknowledgements for financial support are due to Dr B. Hicks of Pacific Aqua Salmon Farming Partnerships of Vancouver, BC, a scholarship (to J.D.W.M.) from the Science Council of British Columbia, and a research grant (to J.M.W.) from the Natural Sciences and Engineering Research Council.

\section{LITERATURE CITED}

Bartholomew JL (1998) Host resistance to infection by the myxosporean parasite Ceratomyxa shasta: a review. $J$ Aquat Anim Health 10:112-120

Clifton-Hadley RS, Richards RH, Bucke D (1986) Proliferative kidney disease (PKD) in rainbow trout, Salmo gairdneri: further observations on the effect of water temperature. Aquaculture 55:165-171

Csaba G (1976) An unidentifiable extracellular sporozoan parasite from the blood of the carp. Parasitol Hung 9: $21-24$

Egusa S (1986) The order Multivalvulida Shulman, 1959 (Myxozoa; Myxosporea): a review. Fish Pathol 21:261-274 (in Japanese)

El-Matbouli M, Hoffmann RW, Mandok C (1995) Light and electron microscopic observations on the route of the triactinomyxon-sporoplasm of Myxobolus cerebralis from the epidermis into rainbow trout cartilage. J Fish Biol 46: 919-935

Ferguson HW (1981) The effects of water temperature on the development of proliferative kidney disease in rainbow trout, Salmo gairdneri Richardson. J Fish Dis 4:175-177

Foott JS. Hedrick RP (1987) Seasonal occurrence of the infectious stage of proliferative kidney disease (PKD) and resistance of rainbow trout, Salmo gairdneri Richardson, to reinfection. J Fish Biol 30:477-483

Gilchrist JDF (1924) A protozoal parasite (Chloromyxum thyrsites sp.n.) of the Cape sea-fish, the 'snoek' (Thyrsites atun, Euphr.). Trans R Soc S Afr 11:263-273

Hervio DML, Kent ML, Khattra J, Sakanari J, Yokoyama $H_{\text {, }}$ Devlin RH (1997) Taxonomy of Kudoa species (Myxosporea), using a small-subunit ribosomal DNA. Can J Zool 75:2112-2119

Kabata Z, Whitaker DJ (1981) Two species of Kudoa (Myxosporea: Multivalvulida) parasitic in the flesh of Merluccius productus (Ayres, 1855) (Pisces: Teleostei) in the Canadian Pacific. Can J Zool 59:2085-2091

Kent ML. Hedrick RP (1986) Development of the PKX myxosporean in rainbow trout Salmo gairdneri. Dis Aquat Org $1: 169-182$

Kent ML, Poppe TT (1998) Diseases of seawater netpenreared salmonid fishes. Quadra Printers, Nanaimo

Kent ML, Margolis L, Whitaker DJ, Hoskins GE, McDonald TE (1994) Review of Myxosporea of importance in salmonid fisheries and aquaculture in British Columbia. Folia Parasitol 41:27-37

Lom J, Dyková I (1988) Sporogenesis and spore structure in Kudoa lunata (Myxosporea, Multivalvulida). Parasitol Res 74:521-530

Lom J, Dyková I (1992) Protozoan parasites of fishes. Elsevier Science Publishers, Amsterdam 
Lom J, Dyková I (1995) Myxosporea (phylum Myxozoa). In: Woo PTK (ed) Fish diseases and disorders, Vol 1: Protozoan and metazoan infections. $\mathrm{CAB}$ International, Wallingford, p 97-148

Lom J, Dyková I, Lhotáková S (1983) Kudoa lunata n.sp. (Myxozoa, Myxosporea) and notes on the nature of muscular 'cysts' of the genus Kudoa. Arch Protistenkd 127:387-397

Lom J, Dyková I, Feist S (1989) Myxosporea-induced xenoma formation in pike (Esox lucius L.) renal corpuscles associated with Myxidium lieberkuehni infection. Eur J Protistol 24:271-280

Morado JF, Sparks A (1986) Observations on the host-parasite relations of the Pacific whiting, Merluccius productus (Ayres), and two myxosporean parasites, Kudoa thyrsites (Gilchrist, 1924) and K. paniformis Kabata \& Whitaker, 1981. J Fish Dis 9:445-455

Moran JDW, Kent ML (1999) Kudoa thyrsites (Myxozoa: Myxosporea) infections in pen-reared Atlantic salmon in the eastern North Pacific Ocean, with a survey of potential nonsalmonid reservoir hosts. J Aquat Anim Health 11: 101-109

Moran JDW, Whitaker DJ, Kent ML (1999a) A review of the myxosporean genus Kudoa Meglitsch, 1947, and its impact on the international aquaculture industry and commercial fisheries. Aquaculture 172:163-196

Moran JDW, Whitaker DJ, Kent ML (1999b) Natural and

Editorial responsibility: Wolfgang Körting,

Hannover, Germany laboratory transmission of the marine myxozoan parasite Kudoa thyrsites to Atlantic salmon. J Aquat Anim Health 11:110-115

Moser M. Kent ML (1994) Myxosporea. In: Kreier JP (ed) Parasitic Protozoa, 2nd edn, Vol 8 . Academic Press, San Diego, p 265-318

Stehr C (1986) Sporogenesis of the myxosporean Kudoa paniformis Kabata \& Whitaker, 1981 infecting the muscle of the Pacific whiting, Merluccius productus (Ayres). J Fish Dis 9:493-504

Stehr C, Whitaker DJ (1986) Host-parasite interaction of the myxosporeans Kudoa paniformis Kabata \& Whitaker, 1981 and Kudoa thyrsites (Gilchrist, 1924) in the muscle of Pacific whiting, Merluccius productus (Ayres): an ultrastructural study. J Fish Dis 9:505-517

St-Hilaire S, Ribble C, Whitaker DJ, Kent M (1998) Prevalence of Kudoa thyrsites in sexually mature and immature pen-reared Atlantic salmon (Salmo salar) in British Columbia, Canada. Aquaculture 162:69-77

Whitaker DJ, Kent ML (1991) Myxosporean Kudoa thyrsites: a cause of soft flesh in farm-reared Atlantic salmon. J Aquat Anim Health 3:291-294

Whitaker DJ, Kent ML, Sakanari JA (1996) Kudoa miniauriculata n.sp. (Myxozoa, Myxosporea) from the musculature of bocaccio (Sebastes paucispinis) from California. J Parasitol 82:312-315

Submitted: February 23, 1999; Accepted: May 28, 1999 Proofs received from author(s): August 13, 1999 